\title{
ОСОБЛИВОСТІ ФУНКЦІОНУВАННЯ ФРАЗЕОЛОГІЗМІВ 3 НАЗВАМИ ДИКИХ ПТАХІВ У СУЧАСНІЙ УКРАЇНСЬКІЙ МОВІ
}

Статтю присвячено дослідженню особливостей функиіонування фразеологізмів з компонентом-орнітономеном у сучасній украйнській мові. Об’єкт фразеологіі розглянуто в широкому розумінні - до иьього проміжного рівня відносимо як ідіоми, так і прислів'я, приказки, усталені образні порівняння тощьо. Проаналізовано назви диких птахів, що входять до складу фразеологічних одиниць із наданням ім особливої маркованості. Визначено національно-культурну специфіку орнітономенів, установлено частоту іх уживання в зазначених мовних одинииях.

Ключові слова: фразеологічні одиниці, орнітофразеологізми, орнітономени, назви птахів, національно-культурна специбіка.

Shulenok O. Peculiarities of the Functioning of Phraseological Units with the Names of Wild Birds in the Modern Ukrainian Language. In the Ukrainian language there is a significant number of established units, which include the names of wild birds giving these phraseological units a special connotation. The object of phraseology in the broadest sense of the word is considered in this article. This intermediate level includes both idioms and proverbs, established figurative comparisons, etc.

The article is devoted to the study of the peculiarities of the functioning of phraseological units with the ornithonym component in the modern Ukrainian language. The topic of the article is relevant due to the fact that idioms with the names of birds are common in the Ukrainian language and constitute a significant group of established units. However, despite the large number of scientific papers on the study of idioms with the names of animals, they need more comprehensive study. The aim of our article is to systematize and analyze the peculiarities of the functioning of phraseological units with the names of wild birds in the modern Ukrainian language. The object of our research is phraseological units with ornithonym component in the modern Ukrainian language. The subject of the research is the functional and ethnocultural features of idioms with the names of birds in the modern Ukrainian language.

The names of wild birds that are a part of the phraseological units are analyzed. The specifics of ornithonyms are determined and the frequency of their use in the Ukrainian phraseological units is established. We recorded the largest number of phrases with the following ornithonyms: ворона /crow/, горобець /sparrow/, сорока /magpie/, соловейко /nightingale/, сова /owl/, орел/еagle/, сокіл/falcon/. The names of other birds (журавель /crane/, синиия /tit/, зозуля /сисkоo/, ластівка /swallow/, ворон/raven/, пава /peacock/, etc.) are less used in the units of analysis. 
It is established that idioms with ornithonym component help to study the ideas of people about the world, about the role of certain birds in their lives. In Ukrainian culture, to characterize someone's behaviour, appearance or way of life, people choose those birds whose habits and way of life are well known to them. Thus, phraseological units with ornithonym component not only contribute to the diversity of speech, but also express the national and cultural specifics of the Ukrainian people.

Key words: phraseological units, idioms with ornithonym component, ornithonyms, names of birds, national-cultural specifics.

\section{Вступ}

Фразеологізми являють собою специфічні мовні формули «картини світу» із закодованою інформацією про минуле, про наших предків, про їхній спосіб сприйняття світу і їхню оцінку всього сутнього; вони акумулюють культурний потенціал народу, маніфестують дух і неповторність ментальності нації (Ужченко, \& Ужченко, 2005: 6).

В українському мовознавстві зооніми як компоненти фразеологічних одиниць уже були об'єктом наукового аналізу. Цій проблемі присвячено праці І. О. Голубовської (2003), О. П. Левченко (2001), О. I. Панченко (2014), I. А. Салати (2010), Д. В. Ужченка (2000) та інших дослідників. Проте саме фразеологізми-орнітономени простудійовано в україністиці лише почасти в названих роботах.

Актуальність теми статті зумовлена тим, що фразеологізми з назвами птахів $€$ поширеними в українській мові та становлять значну групу усталених одиниць, однак, незважаючи на чималу кількість наукових праць, присвячених дослідженню зоофразеологізмів, потребують більш комплексного вивчення.

Мета статті - систематизація й аналіз особливостей функціонування фразеологізмів із назвами диких птахів у сучасній українській мові. Поставлена мета зумовлює розв'язання таких основних завдань: 1) виокремити й схарактеризувати назви диких птахів у складі фразеологізмів української мови; 2) встановити частоту вживання назв диких птахів у складі фразеологічних одиниць; 3) виявити лінгвокультурні особливості орнітофразеологізмів; 4) дослідити особливості функціонування орнітофразеологізмів у художніх та публіцистичних текстах.

Об'єктом дослідження є фразеологізми з компонентом-орнітономеном у сучасній українській мові. Предмет дослідження - функціональні й етнокультурні особливості фразеологізмів із назвами 
птахів у сучасній українській мові. Матеріалом дослідження слугував значний корпус орнітофразеологізмів (понад 350 одиниць) сучасної української мови, вилучених шляхом суцільної вибірки з лексикографічних джерел.

\section{Методи дослідження}

Для розв'язання поставленої мети й завдань дослідження використано такі методи: суцільної вибірки - для отримання корпусу фразеологізмів із назвами диких птахів; описовий - для наукової систематики фразеологізмів із компонентом-орнітономеном; системний - для розподілу орнітономенів за основними типами, групами й підгрупами; культурологічний - для визначення національно-культурних конотацій, завдяки яким орнітофразеологізми відтворюють характерні риси народного менталітету в процесі їх уживання; частково метод кількісних підрахунків - для кількісно-якісної характеристики функціонування орнітономенів у досліджуваних фразеологічних одиницях.

\section{Виклад основного матеріалу}

На жаль, у сучасній українській і зарубіжній лінгвістиці поки що бракує єдиного й місткого визначення фразеологічної одиниці. Під фразеологізмом розуміємо семантично пов'язане сполучення слів, що, на відміну від подібних до нього за формою синтаксичних структур (словосполучень чи речень), не створюється в процесі мовлення відповідно до загальних граматичних і значеннєвих закономірностей поєднання слів, а відтворюється у вигляді фіксованої конструкції 3 властивим їй лексичним складом і значенням (СУЛМ, 2002: 203). У цій статті, спираючись на роботи О. І. Єфімова (1961), О. О. Селіванової (2006), Л. Г. Скрипник (1973), розглядаємо об’єкт фразеології в широкому розумінні цього слова - до цього проміжного рівня відносимо як ідіоми, так і прислів'я, приказки, крилаті вислови, афоризми, сентенції, усталені образні порівняння, стійкі терміносполучення, примовки тощо.

У лінгвістиці найбільш повною вважають класифікацію, у якій фразеологізми з компонентом-зоонімом поділяються на шість окремих груп: власне зоофразеологізми, орнітофразеологізми, ентомофразеологізми, іхтіофразеологізми, рептиліофразеологізми, амфі- 
біофразеологізми. Зоофразеологізми й орнітофразеологізми містять по дві окремі підгрупи: фразеологізми з компонентом, що є назвою дикої або домашньої тварини, птаха (Передерій, 2015: 193).

Інтерес до вивчення зоофразеологізмів, зокрема орнітофразеологізмів, можна пояснити тим, що в образах, створених за допомогою зоонімів, розкриваються риси тварин, які людина переносить на себе. Для характеристики своєї поведінки, зовнішності або способу життя вона обирає тих тварин, звички й спосіб життя яких ій добре знайомі. Отже, інтерпретація зооморфного образу й аналіз фразеологізмів з анімалістичним компонентом дають змогу виявити особливості уявлення людини про саму себе й про світ, що її оточує (Семенова, 2018: 113).

Назви птахів у процесі поступового пізнання людиною довкілля, виокремлення їх із-поміж інших живих істот закарбовано в усталених одиницях. Метафоризацію чи метонімізацію значень орнітономенів за асоціативною зовнішньою чи внутрішньою подібністю $з$ референтами активно використовували в усній народній творчості. Саме у фольклорі склалося традиційне уявлення про характери птахів, засноване на багатовікових спостереженнях за їхніми звичками та способом життя (ворона - чорна, голодна; горобець - жвавий, веселий тощо) (Новикова, 2015: 45).

Дослідивши зібраний значний корпус орнітофразеологізмів української мови, ми виокремили та проаналізували стійкі одиниці 3 компонентами-орнітономенами диких птахів. В українській мові кількісні дані виявилися такими: група “дикі птахи” нараховує понад 350 ФО.

В українській фразеології в групі “дикі птахи” виокремлено такі опорні орнітономени: ворон (крук), ворона, галка, гоголь, горлиия, горобеиь, грак, sава, деркач, дрізд, дятел, жайворонок, журавель, зозуля, іволга (вивільга), каня, кібчик (кібець), кулик, ластівка, лебідь, лелека, лунь, одуд, орел, пава, павич, перепелиия, пугач, синиия, сич, снігур, сова, сокіл, соловейко, сорока, страус, тетеря, фенікс, чайка, чапля, чечітка, шпак, шуліка, яструб.

Зібраний фактичний матеріал переконливо доводить, що в українській фразеології серед назв диких птахів найпоширенішим $є$ орнітономен ворона. Ворона - хижий птах із чорним або сірим оперенням, що живе на деревах поблизу людських поселень. В українців ця птаха 
уособлює лиховісність, їі каркання не провіщає нічого доброго. Разом із гайворонами та кречетами іноді влаштовують зловісні хороводи, які віщують загальну біду (Жайворонок, 2006: 116-117). Із цим орнітономеном зафіксовано 60 ФО: ворон тічити «нічого не робити; байдикувати»; не каркай, як та ворона «уживається в розмові як застереження від чогось небажаного»; впіймати ворону «не зорієнтувавшись вчасно, втратити слушну нагоду, пропустити що-небудь»; біла ворона «той, хто виділяється серед інших чимось незвичайним, зовсім не схожий на інших»; ні пава [ŭ] ні ворона (sава) «який нічим не виділяється; посередній, ніякий (про людину)»; ворона вороні ока не виклює «один одному не буде шкодити»; лякана (полохана і т. ін.)

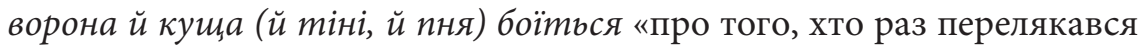
і потім усього боїться; дуже обережний»; пізнати ворону по пір'ю «видно справжню суть людини з ії поведінки» та ін. Приклади вживання зазначених ФО фіксуємо в художній літературі: Тепер ви розумієте, чому треба стати болільником? Щоб не відставати від життя, щоб не бути білою вороною на стадіоні, в товаристві й m. n. (О. Чорногуз). Крім того, ФО біла ворона поширена в публіцистичному стилі: Бути «білою вороною» означає відчувати свою невідповідність; Шлях "білої ворони" до самодостатньої особистості починається з усвідомлення, що немає «гірших і кращих». Інший - ие просто інший (Волошина, 2020).

В українських фразеологізмах досить часто вживаними $є$ й інші назви птахів. Горобець - маленький сірий птах, який живе переважно поблизу житла людини. В українській культурі названому птахові притаманна шлюбна символіка, а також характер спритності, моторності, злодійства. Крім того, у народному світосприйманні горобець набув недоброї слави - якщо б’ється в шибку, то в родині буде покійник або погані вісті. Горобець - єдиний із птахів, що не святкує Благовіщення і в'є у цей день гніздо (Жайворонок, 2006: 146-147).

Орнітономен горобець засвідчено в 47 фразеологічних одиницях: i горобець у роті не наслідив «хто-небудь дуже голодний, зовсім нічого не їв»; стріляний горобець «досвідчена людина, яку важко перехитрити, ошукати»; горобиі иввірінькають у голові «хто-небудь легковажний, несерйозний»; щоб тебе горобці подзьобали «уживається як жартівливе побажання»; за горобия (як у горобия) «дуже мало»; давати горобиям дулі «сидіти без діла; тинятися, байдикувати» та ін. Пор. ФО 
3 орнітономеном горобець, ужиту в художньому стилі: Башта допливла, порівнялася зі мною, і я, стріляний горобещь, під чорним дулом ії гармати мимоволі пригнувся, зігнувся і відчув, як у роті зсохся язик... (М. Вінграновський). Наведемо приклад вживання ФО в публіцистичному стилі: Для неї ией політ перший, а для ї̈ колеги Метью Ковальскі - космонавта зі стажем (Джордж Клуні) - останній. I ией стріляний горобець дрейбує у космосі, розповідає байки диспетчерам, слухає кантрі у вбудованому в скафандр програвачі, милується сходом сония, словом, прощається з відкритим космосом (Дацюк, 2013).

Сорока - лісовий птах родини воронових із довгим хвостом і чорно-білим пір'ям, що видає характерні звуки - скрекотіння, яке українці здавна пов’язують із віщуванням новини, не завжди доброї, а також гостей (Жайворонок, 2006: 568-569).

Аналізований орнітономен зафіксовано в 34 одиницях: сорока на хвості (на крилі) принесла «кому-небудь стало відомо про щось»; як (мов) сорока на хвості розносить (рознесла) «дуже швидко поширюються якісь чутки»; (дивитися) як сорока в (на голу) кістку «дуже уважно»; (сидіти) як сорока на тину «незручно, неприродно»; (жити) як сорока на тину «невлаштовано, непостійно»; (вертітися) як сорока на тину «неспокійно»; (писати) як сорока лапою (по тину) «незграбно, неакуратно» та ін. Наведемо переконливий приклад уживання зазначених ФО в художній літературі: Тепер Борух, як сорока на хвості, рознесе по всіх усюдах про весілля (І. Нечуй-Левицький). Також фіксуємо названі ФО в публіцистиці: Не встигли «янголи» відсвяткувати народження донечки їхної моделі Бехаті Прінслу та Адама Лівайна, як сорока на хвості принесла звістку про те, що ще один «янгол», 27-річна Кендіс Свейнпол, в одній із клінік Лос-Анжелеса народила первістка (Квач, 2016).

Соловейко - маленький перелітний птах із сірим оперенням, самець якого чудово співає, особливо в період гніздування. В українській культурі - Божа, свята пташка, вісник весни. Соловей також символізує досконалість співу, а також одну з жіночих принад - «голос солов їний» (Жайворонок, 2006: 560-562).

Орнітономен соловейко представлено у 25 ФО: співати (виводити, розливатися, заливатися) соловейком (солов'єм) «із надмірним запалом, довго і пишномовно висловлюватися, говорити про що-небудь»; як у спасівку соловейко заспіває «ніколи (уживається для 
вираження повного заперечення змісту речення)»; соловей співає, поки дітей не виведе; золота клітка солов'я не тішить; хоч соловейко маленький, та його пісні удаленькі та ін. ФО з орнітономеном соловейко поширені в художній літературі: Марися. Люблю другого, йому слово подала, $і$ не розлучить нас ніхто - хіба могила, а за вас я тоді вийду заміж, як у спасівку соловейко заспіває! (І. Карпенко-Карий).

Сова - хижий нічний птах із великою круглою головою, великими очима й коротким гачкуватим дзьобом. В українській лінгвокультурі сова має переважно негативну конотацію. В античній Греції сова була символом мудрості (Жайворонок, 2006: 558-559).

Орнітономен сова фігурує в складі 24 ФО: не бачити смаленої сови «бути недосвідченим, не зазнавати труднощів, випробувань у житті»; ні сич, ні сова «ніхто не дізнався»; (лізти) як сова «настирливо; із широко розкритими очима»; як сови ночували в голові «хто-небудь відчуває сильний головний біль від утоми, безсоння»; (дивитися) як сови «широко відкритими очима»; (очі) як у сови «дуже великі, широко відкриті» та ін. Переконливі приклади активного функціонування таких ФО засвідчено в художній літературі: Але, звичайно, ніхто про те не відав - ні сии, ні сова, ні наймудрішого сатани голова (Є. Гуцало); Коли в Химки очі, як у сови, а своїм кирпатим носом вона чує, як у небі млинці печуть. А як ходить, то неначе речетом горох точить, такі викрутаси виробляє... (І. Нечуй-Левицький).

Орнітономен сокіл також представлено в багатьох фразеологічних висловах. Зафіксовано 18 ФО з назвою цього птаха: як (мов, ніби) nідстрелений сокіл «не володіючи собою, безсило, важко, опуститися на що-небудь»; знати сокола по польоту, а доброго молодия по походці; сокола з рук не пускай; людям таке, як постіл, а мені таке, як сокіл; хоч би сова попід небом літала, то соколом не буде; і сокіл вище сония не літає та ін. ФО з орнітономеном сокіл представлено в художній літературі: Що ж робити? Видно пана по походу, а сокола по польоту. Видно було і мене всюди: того ні утаїш, ні заховаєщ, всюди воно перед моїми й чужими очима... (П. Мирний); «І сокіл вище сония не літає». Це так. Не літає. Вище сонечка, але очевидно він всеж таки літає вище всіх крилатих, коли про нього і в прислів'і згадується (В. Чемерис).

Зібраний фактичний матеріал засвідчив, що менш поширеними у ФО української мови є такі назви диких птахів: ворон (крук), галка, грак, sава, журавель, зозуля, каня, кулик, ластівка, лебідь, лелека, лунь, 
орел, пава, пугач, синиия, сич, снігур, тетеря, чайка, чапля, шпак, яструб. Наприклад, ловити sави (saв) «марно витрачати час; байдикувати»; ні пава [ц̆] ні sава (ворона) «який нічим не виділяється; посередній, ніякий (про людину)»; журавель у небі «щось цінне, значне; мрія, яка не може здійснитися»; зозуля закує «хтось помре»; пасти ластів'ят «бездумно вдивлятися у кого-, що-небудь»; лебедина пісня (лебединий сnів) «останній (переважно найвизначніший) твір, вияв таланту, діяльності кого-небудь»; лелека приніс «хто-небудь народився» та ін.

Крім того, ми зафіксували поодинокі випадки вживання назв диких птахів в складі усталених зворотів: гоголь, горлиия, деркач, дрізд, дятел, іволга (вивільга), жайворонок, кібчик (кібеиь), одуд, павич, перепелиия, страус, бенікс, чечітка, шуліка. Наприклад, брехач - як деркач: усе дерчить; хто б дятла знав, якби не його ніс; не прилетів соловей, нехай же іволга за нього править; собака жайворонка ловив та й господаря згубив; кібчик - птичка невеличка, та пазурі гострі та ін.

\section{Висновки}

Отже, завдяки орнітофразеології ми вивчаємо уявлення народів про світ, бачення та розуміння себе в ньому, про роль тих чи тих птахів у житті етносів. Компоненти-орнітономени дають змогу з'ясувати й систематизувати не досліджені раніше функціонально-семантичні особливості фразеологізмів. На основі зібраного й простудійованого матеріалу констатуємо, що ФО з назвами диких птахів позначають різноманітні позитивні й негативні ментальні риси українців, найвиразнішими 3-поміж яких є: сміливість, досвідченість, обережність, балакучість, неуважність, боягузтво, лінощі, метушливість, легковажність та ін. В українській мові наявна значна кількість усталених одиниць, до складу яких входять назви диких птахів, що надають цим ФО особливої маркованості. Найбільше ФО зафіксовано з такими орнітономенами: ворона, горобець, сорока, соловейко, сова, орел, сокіл. Назви інших птахів (журавель, синиия, зозуля, ластівка, сии та ін.) $є$ менш уживаними в складі досліджуваних одиниць, проте вони також сприяють урізноманітненню мовлення та відображають національно-культурну специфіку.

Перспективу дослідження вбачаємо у вивченні семантичних і структурних особливостей фразеологізмів із назвами свійських птахів у сучасній українській мові. 


\section{ЛІТЕРАТУРА}

1. Білодід, І. К. (Ред.). (1970-1980). Словник української мови. (Т. 1-11). Київ: Наук. думка. 2. Білоноженко, В. М., Гнатюк, І. С., Дятчук, В. В., Неровня, В. Н., \& Федоренко, Т. О. (2003). Словник фразеологізмів української мови. Київ: Наук. думка. 3. Голубовська, I. О. (2003). Метафорико-символічні іпостасі зоонімів у рамках фрагмента мовної картини світу «царство тварин». Мовознавство, 6, 61-68. 4. Грищенко, А. П. (Ред.). (2002). Сучасна украйнська літературна мова. Київ: Вища шк. 5. Ефимов, А. И. (1961). Стилистика художественной речи. Москва: Москов. гос. ун-т им. М. В. Ломоносова. 6. Жайворонок, В. В. (2006). Знаки украйнської етнокультури. Київ: Довіра. 7. Кононенко, В. І. (1996). Символи украӥнської мови. Івано-Франківськ: Плай. 8. Левченко, О. П. (2001). Принципи зооцентризму у фразеотворенні. Проблеми зіставної семантики, 5, 206-209. 9. Мишанич, С. В., \& Пазяк, М. М. (1984). Украӥнські прислів'я та приказки. Київ: Дніпро. 10. Новикова, Ю. М. (2015). Лексикосемантична інтерпретація українських і російських фразеологічних одиниць із компонентами-назвами птахів. Мир науки и инновациц̆, 1 (2), 44-49. 11. Панченко, О. І. (2014). Фразеологізми з компонентом-зоонімом в українській та англійській мовах. уч. зап. Тавр. наи. ун-та им. В. И. Вернадского. Серия «Филология. Социальные коммуникации», 66 (27), 111-114. 12. Передерій, I. I. (2015). Класифікація фразеологічних одиниць з зоонімним компонентом у німецькій мові. Наук. зап. Нац. унmу «Острозька академія». Серія «Філологічна», 55, 191-194. 13. Салата, I. А. (2010). Особливості семантичного й прагматичного аспектів зооморфних фразеологізмів в англійській та українській мовах. Філологічні студіi, 5, 57-64. 14. Селіванова, О. О. (2006). Сучасна лінгвістика: термінологічна енциклопедія. Полтава: Довкілля-К. 15. Семенова, О. В. (2018). Семантико-прагматичні особливості зоофразеологізмів. Закарпатські філологічні студіï, 7 (1), 112-115. 16. Скрипник, Л. Г. (1973). Фразеологія украӥнської мови. Київ: Наук. думка. 17. Ужченко, В. Д., \& Ужченко, Д. В. (1998). Фразеологічний словник української мови: близько 2500 виразів. Київ: Освіта. 18. Ужченко, В. Д., \& Ужченко, Д. В. (2005). Фразеологія сучасної української мови. Луганськ: Альма-матер. 19. Ужченко, Д. В. (2000). Семантика українських зоофразеологізмів в етнокультурному висвітленні. (Автореф. дис. ... канд. філол. наук). Харків: Харк. держ. пед. ун-т імені Г. С. Сковороди.

\section{ПУБЛІЦИСИЧНІ ДЖЕРЕЛА}

20. Волошина, Л. (2020). «Біла ворона»: як особистості вижити у колективі. Украйнська правда. Узято 3 https://ife.pravda.com.ua/columns/2020/09/19/242359/. 21. Дацюк, Г. (2013). Порожнеча в ілюмінаторі. Україна Молода, 145. Узято з https:// umoloda.kyiv.ua/number/2345/164/83422/. 22. Квач, А. (2016). Пташеня для янгола. Украйна Молода, 128. Узято з https://umoloda.kyiv.ua/number/3060/119/104488/.

\section{REFERENCES}

1. Bilodid, I. K. (Ed.). (1970-1980). Slovnyk ukrainskoi movy [Dictionary of the Ukrainian language]. (Vol. 1-11). Kyiv: Nauk. dumka [in Ukrainian]. 2. Bilonozhenko, V. M., Hnatiuk, I.S., Diatchuk, V. V., Nerovnia, V.N., \&Fedorenko, T.O.(2003).Slovnykfrazeolohizmiv ukrainskoi movy [Dictionary of phraseology of the Ukrainian language]. Kyiv: Nauk. dumka [in Ukrainian]. 3. Holubovska, I. O. (2003). Metaforyko-symvolichni ipostasi zoonimiv 
u ramkakh frahmenta movnoi kartyny svitu «tsarstvo tvaryn» [Metaphorical and symbolic incarnations of zoonyms within a fragment of the linguistic picture of the world «animal kingdom»]. Movoznavstvo - Linguistics, 6, 61-68 [in Ukrainian]. 4. Hryshchenko, A. P. (Ed.). (2002). Suchasna ukrainska literaturna mova [Modern Ukrainian literary language]. Kyiv: Vyshcha shk. [in Ukrainian]. 5. Efimov, A. I. (1961). Stilistika xudozhestvennoj rechi [The stylistics of fiction speech]. Moskva: Moskov. gos. un-t im. M. V. Lomonosova [in Russian]. 6. Zhaivoronok, V. V. (2006). Znaky ukrainskoi etnokultury [Signs of Ukrainian ethnoculture]. Kyiv: Dovira [in Ukrainian]. 7. Kononenko, V. I. (1996). Symvoly ukrainskoi movy [Symbols of the Ukrainian language]. Ivano-Frankivsk: Plai [in Ukrainian]. 8. Levchenko, O. P. (2001). Pryntsypy zootsentryzmu u frazeotvorenni [Principles of zoocentrism in phrase formation]. Problemy zistavnoi semantyky - Problems of comparative semantics, 5, 206-209 [in Ukrainian]. 9. Myshanych, S. V., \& Paziak, M. M. (1984). Ukrainski pryslivia ta prykazky [Ukrainian proverbs and sayings]. Kyiv: Dnipro [in Ukrainian]. 10. Novykova, Yu. M. (2015). Leksyko-semantychna interpretatsiia ukrainskykh i rosiiskykh frazeolohichnykh odynyts iz komponentamy-nazvamy ptakhiv [Lexical-semantic interpretation of Ukrainian and Russian phraseological units with components-names of birds]. Mir nauki i innovacij - The world of science and innovations, 1 (2), 44-49 [in Ukrainian]. 11. Panchenko, O. I. (2014). Frazeolohizmy z komponentom-zoonimom v ukrainskii ta anhliiskii movakh [Phraseologisms with a zoonym component in Ukrainian and English]. Uch. zap. Tavr. nac. un-ta im. V. I. Vernadskogo. Seriya «Filologiya. Social'nye kommunikacii» - Scientific notes of Tavrida National V. I. Vernadsky University. Series «Philology. Social communications», 66 (27), 111-114 [in Ukrainian]. 12. Perederii, I. I. (2015). Klasyfikatsiia frazeolohichnykh odynyts z zoonimnym komponentom u nimetskii movi [Classification of phraseological units with a zoonymic component in German]. Nauk. zap. Nats. un-tu «Ostrozka akademiia». Seriia «Filolohichna» - Scientific notes of the National University "Ostroh Academy». Series «Philological», 55, 191-194 [in Ukrainian]. 13. Salata, I. A. (2010). Osoblyvosti semantychnoho y prahmatychnoho aspektiv zoomorfnykh frazeolohizmiv v anhliiskii ta ukrainskii movakh [Features of semantic and pragmatic aspects of zoomorphic phraseology in English and Ukrainian]. Filolohichni studii - Philological studies, 5, 57-64 [in Ukrainian]. 14. Selivanova, O. O. (2006). Suchasna linhvistyka: terminolohichna entsyklopediia [Modern linguistics: terminological encyclopedia]. Poltava: Dovkillia-K [in Ukrainian]. 15. Semenova, O. V. (2018). Semantyko-prahmatychni osoblyvosti zoofrazeolohizmiv [Semantic and pragmatic features of zoophraseologisms]. Zakarpatski filolohichni studii - Transcarpathian philological studies, 7 (1), 112-115 [in Ukrainian]. 16. Skrypnyk, L. H. (1973). Frazeolohiia ukrainskoi movy [Phraseology of the Ukrainian language]. Kyiv: Nauk. dumka [in Ukrainian]. 17. Uzhchenko, V. D., \& Uzhchenko, D. V. (1998). Frazeolohichnyi slovnyk ukrainskoi movy: blyzko 2500 vyraziv [Phraseological dictionary of the Ukrainian language: about 2500 expressions]. Kyiv: Osvita [in Ukrainian]. 18. Uzhchenko, V. D., \& Uzhchenko, D. V. (2005). Frazeolohiia suchasnoi ukrainskoi movy [Phraseology of the modern Ukrainian language]. Luhansk: Alma-mater [in Ukrainian]. 19. Uzhchenko, D. V. (2000). Semantyka ukrainskykh zoofrazeolohizmiv v etnokulturnomu vysvitlenni [Semantics of Ukrainian zoophraseologisms in ethnocultural aspect]. Extended abstract of candidate's thesis. Kharkiv: Khark. derzh. ped. un-t imeni H. S. Skovorody [in Ukrainian]. 


\section{PUBLITSYSTYCHNI DZHERELA - JOURNALISTIC SOURCES}

20. Voloshyna, L. (2020). «Bila vorona»: yak osobystosti vyzhyty u kolektyvi ["White Crow»: how individuals survive in the team]. Ukrainska pravda - Ukrainian truth. Retrieved from https://ife.pravda.com.ua/columns/2020/09/19/242359/ [in Ukrainian]. 21. Datsiuk, H. (2013). Porozhnecha v iliuminatori [Emptiness in the porthole]. Ukraina Moloda - Young Ukraine, 145. Retrieved from https://umoloda.kyiv.ua/ number/2345/164/83422/ [in Ukrainian]. 22. Kvach, A. (2016). Ptashenia dlia yanhola [A chick for an angel]. Ukraina Moloda - Young Ukraine, 128. Retrieved from https://umoloda. kyiv.ua/number/3060/119/104488/ [in Ukrainian].

Шуленок Олександр Сергійович - молодший науковий співробітник відділу інноваційних технологій в освіті обдарованих; Інститут обдарованої дитини Національної академії педагогічних наук України; аспірант кафедри української мови Інституту філології; Київський університет імені Бориса Грінченка; вул. БульварноКудрявська, 18/2, м.Київ, 04053, Україна.

Tel.: +38-097-797-50-74

E-mail:shulenok@ukr.net

https://orcid.org/0000-0001-5268-2726

Shulenok Oleksandr Serhiiovych - Research Assistant at the Department of Innovation Technologies in the Education of Gifted, Institute of the Gifted Child of the National Academy of Educational Sciences of Ukraine, Postgraduate student at the Department of Ukrainian Language of the Institute of Philology; Borys Hrinchenko Kyiv University, 18/2 Bulvarno-Kudriavska Str., Kyiv, 04053, Ukraine.

Надійшла до редакції 24 березня 2021 року

\section{CITATION}

ДСТУ 8302:2015: Шуленок О. С. Особливості функціонування фразеологізмів з назвами диких птахів у сучасній українській мові. Лінгвістичні дослідження: 36. наук. пр. Харк. нац. пед. ун-ту імені Г. С. Сковороди. Харків, 2021. Вип. 54. Ч. І. C. 14-24. DOI: https://doi.org/ 10.34142/23127546.2021.54.1.02

APA: Шуленок, О. С. (2021). Особливості функціонування фразеологізмів з назвами диких птахів у сучасній українській мові. Лінгвістичні дослідження, 54 (I), 14-24. DOI: https://doi.org/ 10.34142/23127546.2021.54.1.02 